\title{
REVIEW ARTICLE \\ Salmonellosis associated with mass catering: a survey of European Union cases over a 15-year period
}

\author{
A. OSIMANI, L. AQUILANTI AND F. CLEMENTI* \\ Dipartimento di Scienze Agrarie, Alimentari ed Ambientali, Università Politecnica delle Marche, via Brecce \\ Bianche, Ancona, Italy
}

Received 22 January 2016; Final revision 16 May 2016; Accepted 22 June 2016; first published online 18 July 2016

\section{SUMMARY}

Salmonella spp. is the causative agent of a foodborne disease called salmonellosis, which is the second most commonly reported gastrointestinal infection in the European Union (EU). Although over the years the annual number of cases of foodborne salmonellosis within the EU has decreased markedly, in 2014, a total of 88715 confirmed cases were still reported by 28 EU Member States. The European Food Safety Authority reported that, after the household environment, the most frequent settings for the transmission of infection were catering services. As evidenced by the reviewed literature, which was published over the last 15 years (2000-2014), the most frequently reported causative agents were Salmonella Enteritidis and Salmonella Typhimurium serovars. These studies on outbreaks indicated the involvement of various facilities, including hospital restaurants, takeaways, ethnic restaurants, hotels, in-flight catering, one fastfood outlet and the restaurant of an amusement park. The most commonly reported sources of infection were eggs and/or egg-containing foods, followed by meat- and vegetable-based preparations. Epidemiological and microbiological studies allowed common risk factors to be identified, including the occurrence of cross-contamination between heat-treated foods and raw materials or improperly cleaned food-contact surfaces.

Key words: Food safety, foodborne outbreaks, HACCP, raw eggs, Salmonella.

\section{INTRODUCTION}

This review focuses on the role of the catering industry in the spread of salmonellosis in Europe. First, the review describes the main features of the microorganisms belonging to the genus Samonella and of the associated human illness called salmonellosis. The most important issues and criticalities of mass catering

\footnotetext{
* Author for correspondence: Professor F. Clementi Dipartimento di Scienze Agrarie, Alimentari ed Ambientali, Università Politecnica delle Marche, via Brecce Bianche, 60131 Ancona - Italy (Email: f.clementi@univpm.it)
}

are then described. The subsequent overview of current European Union (EU) legislation on matters of food safety places particular emphasis on regulations concerning zoonoses, since salmonellosis is included in the list of zoonoses that have to be properly monitored. The main focus of this paper is the 'case reports' section that reports the information available in the current literature concerning the role of the catering industry in the spread of salmonellosis. In particular, the review reports published studies on the documented occurrence of salmonellosis outbreaks in the EU related to the catering sector between 2000 and 2014. Finally, considering once again the available 
literature, the authors analyse and discuss the possible risk factors that could have contributed to the presence of Salmonella in food preparations, and the achievable corrective actions, as well as the implementation of good manufacturing practices.

The genus Salmonella, which is included in the Enterobacteriaceae family, comprises only two species (Salmonella enterica and S. bongori) of Gramnegative, facultatively anaerobic, non-spore-forming rods $(1-2 \mu \mathrm{m})$. The optimal growth temperature is about $38^{\circ} \mathrm{C}$ (with a minimum of $5^{\circ} \mathrm{C}$ ). Salmonella is generally susceptible to low $\mathrm{pH}$ values, although an acid tolerance response has already been described for many S. enterica serovars [1].

$S$. enterica comprises the following six subspecies: enterica (I), salamae (II), arizonae (IIIa), diarizonae (IIIb), houtenae (IV), and indica (VI), whereas for $S$. bongori no subspecies have been identified [2]. For epidemiological purposes, Salmonella nomenclature is based on the use of over 2400 serovars which differ in their host range and the associated disease. The illness caused by Salmonella is called salmonellosis, which is one of the most frequently reported foodborne pathologies worldwide [3]. The causative agents of the invasive form of salmonellosis are Salmonella enterica serotypes Typhi or Paratyphi A and B, which cause enteric fever, and $S$. Paratyphi C, which causes septicaemia and metastatic purulent infections, or $S$. Enteriditis and $S$. Typhimurium serotypes which cause the invasive non-typhoidal illness [4]. The incubation period of salmonellosis, which is usually selflimiting in 4-7 days, varies between $12 \mathrm{~h}$ and $36 \mathrm{~h}$; typical symptoms of salmonellosis include: diarrhoea, nausea, abdominal pain, bloody stool, mild fever and chills, vomiting, headache and malaise. Plasmids from $50 \mathrm{~kb}$ to $100 \mathrm{~kb}$ have been associated with the virulence of Salmonella, the infective dose of which can vary from 20 to $10^{6}$ cells [3].

As reported by Sanchez-Vargas et al. [2], in cases of uncomplicated gastroenteritis, an antimicrobial therapy is usually not indicated since the disease is generally self-limiting. However, for patients aged $>50$ years, immunosuppressed individuals, and patients with vascular abnormalities or prosthetic valves, grafts or joints, an antimicrobial therapy should be considered, since these subjects can risk invasive disease. Antibiotic treatment normally includes the use of azithromycin, cephalosporins, trimethoprimsulfamethoxazole, or ampicillin [2].

The intestinal tract of a wide range of domestic and wild animals is known to be the most common reservoir of Salmonella which can be transferred to humans and foodstuffs [1].

In the 7-year period between 2008 and 2014, a constant declining trend of salmonellosis was observed in the EU/European Economic Area (EEA) [5]. The EU summary report on trends and sources of zoonoses, zoonotic agents and foodborne outbreaks in 2014 [5] reported a $15 \cdot 3 \%$ increase in the EU notification rate compared to 2013. In 2014, a total of $88715(23 \cdot 4$ cases/100 000 population) confirmed salmonellosis cases were reported by 28 EU Member States (MSs) with a $0 \cdot 15 \%$ case-fatality rate. In parallel, from 2008 to 2014 the total annual number of foodborne Salmonella outbreaks within the EU decreased markedly from 1888 to 1048 . As reported by the European Food Safety Authority (EFSA) and the European Centre for Disease Prevention and Control (ECDC) [5], in 2014, $S$. Enteritidis and $S$. Typhimurium caused a total of 169 outbreaks with strong evidence (in various environments); $S$. Enteritidis was the prevalent causative agent of salmonellosis related to the consumption of eggs and egg products $(46 \cdot 1 \%)$, bakery products $(17 \cdot 0 \%)$, broiler meat and its products $(6 \cdot 4 \%)$, sweets and chocolate $(5 \cdot 0 \%)$, cheese $(4 \cdot 3 \%)$, buffet meals (3.5\%), mixed food and other foodstuffs $(17 \cdot 7 \%)$. The presence of $S$. Typhimurium was the main cause of illnesses associated with pork and its products $(48 \cdot 1 \%)$, eggs and egg products $(29 \cdot 6 \%)$, bakery products $(1 \cdot 0 \%)$, cheese $(1 \cdot 0 \%)$ and other food and food products (crustaceans, molluscs, etc.). Although the number of outbreaks is declining, it should be noted that, after the household environment, the most frequently reported settings for foodborne salmonellosis are still represented by mass catering establishments such as restaurants, cafés, pubs, bars, hotels, and catering services in general (41 outbreaks) [5]. The reduction in cases of salmonellosis in humans is mainly the result of effective Salmonella control programmes in fowl (Gallus gallus) populations, which have led in particular to fewer contaminated eggs. This has been achieved through the combined efforts of food business operators, veterinary public health authorities and policy makers [6].

As regards foods, Salmonella is notifiable in $16 \mathrm{MSs}$ (Belgium, Bulgaria, Czech Republic, Denmark, Estonia, Finland, France, Germany, Hungary, Italy, Latvia, Romania, Slovakia, Slovenia, Spain, Sweden) and in two non-MSs (Norway and Iceland). Information is not available from Cyprus, Croatia, Greece, Lithuania, Luxembourg, Malta, The Netherlands, Poland, Portugal and Switzerland [5]. 


\section{MASS CATERING CONCERNS}

The main objectives of catering systems are related to the production and serving of food products to defined groups of consumers. Such systems are normally characterized by a series of inputs, which include: (i) ready-to-eat or unprocessed foods; (ii) a number of adequately trained operators; (iii) suitable premises and equipment; (iv) availability of any necessary funds [7]. Catering systems are normally divided in two main sectors: the 'cost sector', which includes not-for-profit catering activities such as healthcare, education, business and industry, and public services and the 'profit sector' which includes all profitorientated organizations such as cafés, fast-food outlets, hotels, leisure operations, pubs, restaurants, takeaways and travel organizations [7].

Most catering establishments adopt a 'cook-serve' method in which preparation and serving are almost simultaneous and can therefore be considered as a single operation. Catering services may also be differentiated as food-manufacturing systems, where the serving of food is separate from its production, or meal-assembly/food-delivery systems, where the main activities are just the assembly, regeneration, and serving of meals [7].

All things considered, it is clear that the catering industry is characterized by a complex series of operations aimed at obtaining high-quality finished food products, intended for a wide range of consumers, and hence it is imperative to ensure food safety at each stage along the production chain.

The most common risk factors that can lead to foodborne outbreaks of disease include: poor quality raw materials, inadequate cooking, improper holding temperatures, a lack of hygiene conditions and crosscontamination [8].

\section{THE EUROPEAN FOOD SAFETY APPROACH}

In the $\mathrm{EU}$, food safety procedures are established by Regulation (EC) No. 178/2002 [9], and, in 2005, the European Commission issued the so-called 'Hygiene Package' which brought together the following key provisions: Regulation (EC) No. 852/2004 [10], Regulation (EC) No. 853/2004 [11], Regulation (EC) No. 854/2004 [12], and Regulation (EC) No. 882/ 2004 [13]. The new integrated approach set by the 'Hygiene Package' aimed to clarify and simplify the European legislative framework, while maintaining a high level of public health safety. This approach specifically regulates food hygiene and distinguishes the responsibility of food business operators from that of competent authorities and creates a framework to regulate animal health aspects. The new legal framework supersedes the laws of individual countries and establishes general rules for food hygiene in all foodstuffs as well as specific rules for certain food businesses.

In more detail, as a part of the 'Hygiene Package', European Regulation (EC) No. 852/2004 [10] set obligations for food businesses in relation to food hygiene, establishing their responsibilities for the safety of foodstuffs. With this type of approach, food business operators are required to both decide and monitor measures for controlling any risk to public health. One of the basic obligations provided for by Regulation (EC) No. 852/2004 [10] is that food businesses have to implement permanent procedures based on Hazard Analysis and Critical Control Point (HACCP) principles in order to ensure the safety of foods.

Moreover, Regulation (EC) No. 853/2004 [11], which establishes rules for the organization of official controls on products of animal origin intended for human consumption, specifies that the official veterinarian is to impose the conditions in which animals are to be dealt with, under a specific scheme for the eradication or control of certain diseases, such as brucellosis or tuberculosis, or zoonotic agents such as Salmonella, under his/her direct supervision (chapter III, Decisions concerning live animals).

Among the Regulations contained in the 'Hygiene Package', Regulation (EC) No. 882/2004 [13] on official controls performed to ensure the verification of compliance with feed and food law, animal health and animal welfare rules, states that any more specific pre-existing rules in the areas of feed and food, and of animal health and animal welfare controls, must be applied. Regulation (EC) No. 882/2004 [13] also established community reference laboratories for the analysis and testing of zoonoses (Salmonella).

Moreover, from 1 January 2006, Regulation (EC) No. 2073/2005 [14], as amended by Regulation (EC) No. 1441/2007 [15], indicates microbiological criteria for foodborne bacteria (Salmonella spp., Listeria monocytogenes and Enterobacter sakazakii), microbial toxins (i.e. staphylococcal enterotoxins) and metabolites (i.e. histamine). Such criteria provide points of reference for the evaluation of the HACCP system by food business operators. 
Most European legislation is aimed at protecting human health against diseases and infections which are transmissible directly or indirectly between animals and humans (zoonoses) since these foodborne infections may be the cause of severe social concern and economic losses.

The EU system for the monitoring and collection of information on zoonoses is based on the Zoonoses Directive 2003/99/EC [16] on the monitoring of zoonoses and zoonotic agents, which amended Council Decision 90/424/EEC [17] and repealed Council Directive 92/ 117/EEC [18]; in particular, Directive 2003/99/EC [16] identified Salmonella spp., Campylobacter spp., verotoxigenic Escherichia coli (VTEC), L. monocytogenes, Cryptosporidium spp., Echinococcus granulosus/multilocularis and Trichinella spiralis as public health priorities. In this context EU MSs are responsible for collecting data via their monitoring systems and for the epidemiological investigation of outbreaks. The European Commission also promotes the cooperation and exchange of information and evaluates trends at European level. The collection of data on human diseases from MSs is carried out in accordance with Decision 1082/2013/EU [19] on serious cross-border threats to health, which replaced Decision 2119/98/EC [20] on setting up a network for the epidemiological surveillance and control of communicable diseases in the EU. National zoonoses reports are used as the basis for the EU Summary Reports on Trends and Sources of Zoonoses, zoonotic agents, antimicrobial resistance and foodborne outbreaks in the EU, drawn up each year by the EFSA and the ECDC.

\section{CASE REPORTS}

Despite great progress in the field of food safety, meals produced and served by the catering sector continue to be one of the major causes of foodborne infections and poisoning, with serious social and economic consequences, especially when vulnerable consumers are involved [21]. As reported by Møller and colleagues [22], it is estimated that $70 \%$ of worldwide foodborne illnesses are related to food prepared at food service establishments.

Inadequate application of good manufacturing practices (GMPs) by the staff involved in the preparation of meals at catering facilities and, in particular, the incorrect heat treatment of foods, can be pivotal factors which contribute to outbreaks of foodborne illnesses. The studies described below, emphasise the importance of the proper management of foods, also in relation to the risk associated with the presence of Samonella.

In 2000, an outbreak of salmonellosis, caused by $S$. Enteritidis phage types $5 \mathrm{c}$ and $6 \mathrm{a}$, occurred across Scotland [23]. A total of 70 cases, probably related to the consumption of chicken dishes from Chinese restaurants or takeaways, were recorded. Unfortunately, environmental analyses did not identify the source of chicken contamination.

Following a series of gastrointestinal symptoms affecting consumers who had eaten a meal in a Chinese restaurant in Suffolk (UK) in 2002 [24], an outbreak control team carried out epidemiological, microbiological and environmental investigations. The cohort study found 38 consumers who met the case definition of salmonellosis, of whom two were hospitalized; $S$. Enteriditis phage type 34 a was found in 31 stool specimens subjected to microbiological analyses. The study identified significantly high attack rates related to egg and chicken fried rice; the chef confirmed that the egg mixture used for egg-fried rice was subjected to temperature abuse before serving. Moreover, the environmental inspection highlighted deficiencies in good hygiene practice (i.e. inadequate hand-washing facilities). From the analysis of data, Badrinath and colleagues [24] suspected that dishes containing eggs were the most likely source of the outbreak, suggesting that the use of pasteurized eggs and the correct application of GMPs would have prevented the outbreak.

A buffet consisting of meat, potatoes, pasta, and raw vegetables, was found to be the origin of an outbreak of salmonellosis in Denmark in 2003 [25]. The restaurant involved was part of a catering system of 35 facilities located in an amusement park near Copenhagen. Due to the high number of visitors, 67 cases were confirmed, while a total of 390 cases were estimated as the real number of people infected. Epidemiological and microbiological studies indicated that the contamination of foods was probably caused by an assistant chef who was found to excrete the epidemic strain of $S$. Typhimurium phage type DT104. A non-functional staff toilet, meaning that staff and customers had to use the same toilet facilities, was considered the most probable risk factor.

Following a significant change in the epidemiology of $S$. Enteritidis in England and Wales which was probably due to the use of raw shell eggs, in 2002, the UK Health Protection Agency launched an investigation to determine the contamination and the origin of the eggs used by the catering plants involved in the 
outbreaks. The use of eggs produced in Spain was identified as a risk factor in many of the outbreaks, hence raw shell eggs were prohibited in catering facilities and hospitals. Sixteen phage types were identified in some isolates of $S$. Enteritidis from Spanish eggs [26].

Prior to the 2004 Athens Olympic Games, an integrated environmental health surveillance programme was implemented. During the surveillance activity, in August 2003, an outbreak of salmonellosis occurred, linked to a hotel restaurant which accommodated athletes during a test event. The hotel involved had already been ranked by environmental health surveillance officers as having the most unsatisfactory results even before the outbreak occurred [27].

Irvine and colleagues reported a large outbreak of $S$. Newport that occurred in Northern Ireland during September and October 2004 with 130 reported cases [28]. The statistical analysis carried out on control cases associated the outbreak with the consumption of lettuce (probably iceberg lettuce) in meals produced in fast-food premises (American-style hamburger outlets and fish-and-chip shops); this exposure was reported in $57 \%$ of cases. Unfortunately, no samples of contaminated salads were available for microbiological analyses.

Heissenhuber and colleagues [29] reported a contaminated pudding which was probably responsible for an outbreak of $S$. Enteritidis in hospitals and nursing homes in 2004 in Germany.

In the same year, roast chicken served at a hospital restaurant in Greece was identified as the cause of an outbreak of salmonellosis in 133 patients, visitors and hospital employees [30]. Despite the fact that epidemiological and microbiological investigations indicated $S$. Enteritidis as the causative agent of the outbreak, the source of contamination remained speculative. However, the main risk factors associated with the outbreak could be attributed to a lack of GMPs, including: non-systematic use of gloves and gowns, the use of common surfaces for raw materials and ready-to-eat foods, improper sanitation procedures, inadequate temperature control, and/or inadequate cooking.

Although infection originating in fast-food premises has been rarely described, in 2005, one of the largest outbreaks of enteric infection occurred in a fast-food outlet located in London (UK) [31]. S. Enteritidis was isolated from both stool samples and 14 out of 40 food samples examined. Moreover, an environmental health inspection of the premises highlighted deficiencies in food preparation (i.e. time-temperature abuse in sauce storage) and hygiene. The most serious cases were related to the consumption of chips and salads produced in the same plant.

In the same year carpaccio was identified as the probable source of an outbreak that occurred in an Italian restaurant in Denmark [32, 33]. Eleven customers who had eaten at the restaurant were hospitalized; all the infections were laboratory-confirmed.

In 2008, iceberg lettuce was the most probable source of an infection caused by both $S$. Newport and $S$. Reading in Finland [34]. The ready-chopped lettuce was prepared by institutional kitchens and served in different catering plants; a total of 107 confirmed cases of salmonellosis were reported, and two patients died. Epidemiological and microbiological investigations allowed the source of contamination to be traced back to the lettuce but did not reveal the risk factor.

Janmohamed and colleagues [35] reported the results of an epidemiological investigation after a national outbreak of $S$. Enteritidis phage type 14b that occurred in England in 2009. Sixty-three cases were studied; the study revealed that eating foods from restaurants serving Chinese or Thai cuisine was significantly associated with the illness. Fortunately, no deaths were reported in the cases studied. The source of contamination was found to be eggs originating from Spain used for the preparation of egg meals and vegetarian foods containing eggs. Microbiological analyses on eggs collected from foodservice premises and egg production establishments, revealed the presence of Salmonella in both plants.

In 2014, Zenner and colleagues [36] published the results of a large $S$. Enteritidis outbreak which occurred in a north west London (UK) takeaway restaurant during September 2009. The study was carried out using a new approach based on the analysis of till receipts to assess associations between sales and illness. Analysis of stool samples, from the initial patients with enteric illness, identified $S$. Enteritidis; subsequently, a number of patients went to hospital with symptoms of diarrhoea and vomiting. The epidemiological investigation allowed 66 individuals to be identified, which fulfilled the definition of a probable or confirmed outbreak of salmonellosis. Of these, 31 were classified as confirmed cases by microbiological analyses on stool samples. The data obtained from epidemiological and microbiological analyses and till receipt collection indicated a correlation between the consumption of rotisserie chicken and illness. Cross-contamination between raw and cooked foods, and insufficient recording of temperature control were noted as risk factors. 
In 2010, a retrospective cohort study was conducted to identify the food item(s) most likely to be associated with an outbreak of $S$. Enteritidis phage type 4 that occurred during a soccer camp in Austria [37]. Among the 143 participants, 34 were found to be affected by salmonellosis with an attack rate of $23 \cdot 8 \%$. Epidemiological and microbiological analyses revealed that eggs used as ingredients for spaetzle (homemade noodles) and hamburgers, produced in the hotel that accommodated the soccer camp participants, were considered to be the most probable vehicle of the outbreak strain. The public health authorities which carried out hygiene inspections in the kitchen of the hotel found a lack of food safety practices related to unclean food contact surfaces (including ovens, grills and stoves), improper storage conditions, and inadequate training of kitchen staff.

In the same year (2010) an outbreak of $S$. Enteritidis occurred in a hospital located in Germany [38]. After the epidemiological investigation, the authors identified cheesecake, served by two different cafeterias located in the hospital, as the source of infection. Since neither of the cafeterias prepared the cheesecake, the authorities contacted the bakery which supplied both the catering plants. The bakery was ordered to stop using raw eggs. At the same time the stool of one member of the staff was found positive for the presence of $S$. Enteritidis. The authors suspected that the relatively low cooking temperature of the cheesecake allowed the survival of the pathogens already present in the inner part of the cake.

The consumption of salad leaves at restaurants and/ or purchased from commercial catering organisations was significantly associated with a large outbreak of $S$. Java in the UK in 2010 [39]. The probable crosscontamination between meat products and salads during food preparation in the catering plants was found to be the risk factor.

In 2011, a group of Irish travellers contracted salmonellosis caused by $S$. Heidelberg during their return flight from Tanzania; the symptoms included diarrhoea, abdominal pain, fever, nausea, vomiting and bloody diarrhoea. Rebolledo and colleagues [40] conducted a case-control study in order to establish the source of infection. The study identified milk tart and egg dishes served on board as significantly associated with the outbreak, hence, the producer of the meals, located in Tanzania, was contacted and asked to provide documentation on food preparation procedures. Other passengers from The Netherlands, Norway, USA, and Canada, travelling from Tanzania in the same period, were also contacted. Some of them were found to be positive to the infection; this information contributed to better defining the source of infection (in-flight catering), although the risk factors which contributed to the contamination of foods remained unclear.

After the largest $S$. Newport outbreak, which occurred in Germany in 2011 [41], an analytical epidemiological and microbiological investigation was carried out. The outbreak involved 106 individuals in Germany and 20 associated cases in The Netherlands; the study, which was carried out in parallel in the two countries, traced the contamination of $S$. Newport to mung bean sprouts sampled from both the producer of the sprouts, located in The Netherlands, and the distributor in Germany. Sprouts were served at a clinic salad bar and Asian restaurants in Germany, and in a hospital in The Netherlands. The authors concluded that raw or insufficiently cooked sprouts, which were already naturally contaminated, were the source of the infection.

Recently, Chironna and colleagues [42] reported the results of an investigation carried out after an outbreak of acute gastroenteritis in people who had eaten at an inexpensive restaurant in southern Italy. Laboratory analyses confirmed infection caused by Salmonella which was isolated from a stool sample. A total of 23 cases of gastroenteritis (two of which were hospitalized) were notified. All cases reported symptoms of diarrhoea, fever, abdominal cramps, vomiting and nausea. The kitchen facility in the inexpensive restaurant was subjected to microbiological analyses carried out on the work surfaces including: the porchetta cutting board, the tray table, knife, mincer, handle of freezer and handle of the staff toilet. Porchetta (a typical central Italy speciality) and stool samples were also analysed. Environmental analyses revealed $S$. Infantis on the porchetta cutting board, in the four tested pieces of porchetta and in the stool samples. The stools collected from staff members were also positive for the same pathogen, despite the absence of symptoms.

Recently, Inns and colleagues [43], reported a multi-country outbreak of $S$. Enteritidis phage type 14B in the UK; the food chain investigation allowed the illness to be associated with eggs from a German producer. A total of 287 cases were recorded, of which Salmonella infection was considered to be a contributory factor in the death of one patient. Epidemiological and environmental investigations allowed the pathogen to be sampled from a catering 
trolley in one of the wards of a hospital. Cooked chicken, pork and egg-containing vegetarian noodles sampled in restaurants were also found positive for the presence of Salmonella. Interestingly, the pathogen whole genome sequencing carried out in this study, discovered a link between the isolates from patients, eggs and environmental samples collected in premises and clusters of cases in an outbreak that occurred in several EU MSs.

\section{DISCUSSION}

Although a decreasing trend in the number of cases of salmonellosis has been observed in the EU, Salmonella is still the causative agent of most of the reported foodborne outbreaks in the EU, and in fact salmonellosis is the second most commonly reported gastrointestinal infection in the EU/EEA [44].

The analysis of the reviewed literature, described in detail in the previous section and summarized in Table 1, highlighted the prevalence of the $S$. Enteritidis serovar as the causative agent of the outbreaks, followed by $S$. Typhimurium (found in the cases that occurred in Denmark) and, to a lesser extent, by $S$. Java, $S$. Infantis, $S$. Heidelberg and, $S$. Newport. These findings are in agreement with the data published by the ECDC which reported that, in 2012, the five most commonly reported serotypes of Salmonella belonged to $S$. Enteritidis, $S$. Typhimurium, monophasic $S$. Typhimurium, $S$. Infantis, and $S$. Stanley [44]. As stated by Regulation (EC) No. 2073/2005 [14], it has been demonstrated that the implementation of control programmes can markedly contribute to a reduction in the prevalence of Salmonella in production animals and products thereof. Moreover, Annex I of the same EU Regulation (chapter 1) specified the absence of Salmonella in $25 \mathrm{~g}$ of product placed on the market during shelf-life, except for minced meat and meat preparations made from species other than poultry which are intended to be eaten cooked, and for mechanically separated meat for which the absence of Salmonella in $10 \mathrm{~g}$ of product is required.

As regards the infection environments, the reported outbreaks, which were widespread in several EU countries, showed the involvement of various facilities, including: hospital restaurants, takeaways, ethnic restaurants, hotels, in-flight catering, one fast-food outlet and the restaurant of an amusement park. To the best of the authors' knowledge no Salmonella infections in school catering plants were reported in the considered period. The case studies published over a 15-year period, showed the involvement of about 1300 users, although with a low mortality rate (eight cases). It is worth underlining that each catering environment is characterized by different peculiarities, especially as regards the type of consumer. Among the most critical settings, hospital restaurants can cause outbreaks with the highest mortality rates; as clearly shown in Table 1, 5/8 reported deaths occurred in such facilities. This finding is not surprising, since hospitalized patients can be considered as high-risk consumers.

Regarding the sources of the outbreaks, the traceability system, the implementation of which is guaranteed by the application of Regulation (EC) No. 178/ 2002 [9], has played a key role in tracing the foods (and/or the producers) which caused the outbreaks. Of the 18 reviewed salmonellosis outbreaks (from 2000 to 2014), about one third were related to the consumption of eggs and/or egg containing foods (i.e. egg-fried rice, vegetarian food containing eggs, cheesecake, raw eggs, etc.). This finding is confirmed by the EFSA and ECDC EU Summary Report on Trends and Sources of Zoonoses, Zoonotic Agents and Foodborne Outbreaks [5] which reported that, in 2014, the most important sources of foodborne Salmonella outbreaks were eggs and egg products. In 2010 the Food Safety Authority of Ireland (FSAI) issued Fact Sheet No. 1 [45] which included guidelines for caterers in order to reduce the risk represented by the use of fresh shell eggs and products made from fresh eggs. The reported high-risk dishes include tiramisu, scrambled egg, omelette, quiche, some pastry products, mousse, homemade mayonnaise, homemade ice-cream, hollandaise or similar sauces. Recently, the ECDC and the EFSA [46] have reported a multi-country outbreak of $S$. Enteritidis infection associated with the consumption of eggs from Germany. The ECDC and EFSA also warn that $S$. Enteritidis-contaminated eggs have been able to reach the market, despite the strict regulations applying to table eggs for human consumption, and the success in reducing human and animal infections in recent years within the EU. Hence it is necessary to continue a close monitoring of the occurrence of human cases through the Epidemic Intelligence Information System for Food- and Waterborne Diseases and Zoonoses (EPIS-FWD) and MS surveillance.

Moreover, meat-based products were also considered as an important source of infection. As evidence of the constant efforts made by the scientific 
Table 1. Reported cases of salmonellosis outbreaks related to catering services in the European Union (2000-2014)

\begin{tabular}{|c|c|c|c|c|c|c|c|c|c|}
\hline Year & EU country & $\begin{array}{l}\text { Catering service } \\
\text { involved }\end{array}$ & Food involved & $\begin{array}{l}\text { S. enterica } \\
\text { serovars }\end{array}$ & Cases & $\begin{array}{l}\text { Hospitalized } \\
\text { patients }\end{array}$ & $\begin{array}{l}\text { No. of } \\
\text { deaths }\end{array}$ & Risk factors & Reference \\
\hline 2000 & UK & Chinese food businesses & Chicken dishes & $S$. Enteritidis & 70 & n.r. & 1 & n.r. & Cowden et al. 2003 [23] \\
\hline 2002 & UK & Chinese restaurant & Egg-fried rice & S. Enteritidis & 38 & 2 & 0 & $\begin{array}{l}\text { Cleaning and } \\
\text { maintenance issues, } \\
\text { improper } \\
\text { maintenance } \\
\text { temperature of egg } \\
\text { rice mixture }\end{array}$ & Badrinath et al. 2004 [24] \\
\hline 2003 & Denmark & $\begin{array}{l}\text { Restaurant at an } \\
\text { amusement park }\end{array}$ & Food buffet & $S$. Typhimurium & 77 & n.r. & 0 & $\begin{array}{l}\text { Assistant chef who } \\
\text { excreted the } \\
\text { epidemic strain, } \\
\text { non-functional staff } \\
\text { toilet }\end{array}$ & Ethelberg et al. 2004 [25] \\
\hline 2003 & Greece & Hotel restaurant & n.r. & n.r. & n.r. & n.r. & n.r. & n.r. & $\begin{array}{l}\text { Hadjichristodoulou et al. } \\
2006 \text { [27] }\end{array}$ \\
\hline 2004 & $\begin{array}{l}\text { Northern } \\
\text { Ireland }\end{array}$ & Fast-food premises & Lettuce & S. Newport & 130 & 25 & 0 & n.r. & Irvine et al. 2009 [28] \\
\hline 2004 & Germany & Hospital catering & Pudding & $S$. Enteritidis & n.r. & n.r. & 2 & n.r. & $\begin{array}{l}\text { Heissenhuber et al. } \\
2005 \text { [29] }\end{array}$ \\
\hline 2005 & Greece & Hospital catering & Roast chicken & $S$. Enteritidis & 133 & n.r. & 2 & $\begin{array}{l}\text { Cross-contamination, } \\
\text { inadequate } \\
\text { temperature control } \\
\text { and/or inadequate } \\
\text { cooking }\end{array}$ & Gikas et al. 2007 [30] \\
\hline 2005 & UK & Fast food & $\begin{array}{l}\text { Chips, salad, chilli } \\
\text { sauce, chicken, mint } \\
\text { yogurt sauce }\end{array}$ & $S$. Enteritidis & 81 & n.r. & 0 & $\begin{array}{l}\text { Inadequate heat } \\
\text { treatment practices, } \\
\text { time temperature } \\
\text { abuse, } \\
\text { cross-contamination } \\
\text { of raw and cooked } \\
\text { ingredients, a lack of } \\
\text { hygiene }\end{array}$ & Giraudon et al. 2009 [31] \\
\hline 2005 & Denmark & Restaurant & $\begin{array}{l}\text { Carpaccio (thinly } \\
\text { sliced, raw fillet of } \\
\text { beef) }\end{array}$ & $S$. Typhimurium & 40 & 11 & 0 & $\begin{array}{l}\text { Contaminated raw } \\
\text { meat }\end{array}$ & $\begin{array}{l}\text { Ethelberg, } 2005 \text { [32]; } \\
\text { Ethelberg et al. } 2005 \\
{[33]}\end{array}$ \\
\hline 2008 & Finland & Institutional kitchens & $\begin{array}{l}\text { Ready-chopped } \\
\text { iceberg lettuce }\end{array}$ & $\begin{array}{l}\text { S. Newport, } \\
\text { S. Reading }\end{array}$ & 107 & n.r. & 2 & Uncertain & Lieneman et al. 2011 [34] \\
\hline
\end{tabular}


Table 1 (cont.)

\begin{tabular}{|c|c|c|c|c|c|c|c|c|c|}
\hline Year & EU country & $\begin{array}{l}\text { Catering service } \\
\text { involved }\end{array}$ & Food involved & $\begin{array}{l}\text { S. enterica } \\
\text { serovars }\end{array}$ & Cases & $\begin{array}{l}\text { Hospitalized } \\
\text { patients }\end{array}$ & $\begin{array}{l}\text { No. of } \\
\text { deaths }\end{array}$ & Risk factors & Reference \\
\hline 2009 & UK & Takeaway restaurant & Rotisserie chicken & $S$. Enteritidis & 66 & 22 & 0 & $\begin{array}{l}\text { Cross-contamination } \\
\text { between raw and } \\
\text { cooked foods, } \\
\text { insufficient recording } \\
\text { of temperature } \\
\text { control }\end{array}$ & Zenner et al. 2014 [36] \\
\hline 2009 & UK & $\begin{array}{l}\text { Restaurants serving } \\
\text { Chinese or Thai } \\
\text { cuisine }\end{array}$ & $\begin{array}{l}\text { Eggs, vegetarian food } \\
\text { (containing eggs) }\end{array}$ & $S$. Enteritidis & 63 & 12 & 0 & $\begin{array}{l}\text { Contamination of } \\
\text { laying flocks of eggs } \\
\text { production } \\
\text { establishment }\end{array}$ & $\begin{array}{l}\text { Janmohamed et al. } \\
2011 \text { [35] }\end{array}$ \\
\hline 2010 & Germany & Local pastry supplier & Cheesecake & $S$. Enteritidis & 7 & 4 & 0 & $\begin{array}{l}\text { Cross-contamination, } \\
\text { insufficient cooking } \\
\text { temperature of the } \\
\text { cheesecake }\end{array}$ & Poetter et al. 2014 [38] \\
\hline 2010 & Austria & Hotel & $\begin{array}{l}\text { Spaetzle (homemade } \\
\text { noodles), hamburger }\end{array}$ & $S$. Enteritidis & 34 & n.r. & 0 & $\begin{array}{l}\text { A lack of food safety } \\
\text { practices }\end{array}$ & Liu et al. 2012 [37] \\
\hline 2011 & UK & $\begin{array}{l}\text { Commercial catering } \\
\text { settings }\end{array}$ & Salad vegetables & S. Java & 136 & n.r. & 0 & $\begin{array}{l}\text { Probable cross- } \\
\text { contamination from } \\
\text { meat products } \\
\text { during food } \\
\text { preparation in } \\
\text { catering } \\
\text { establishments }\end{array}$ & Gobin et al. 2011 [39] \\
\hline 2011 & Italy & Hash house & Porchetta & $S$. Infantis & 23 & 2 & 0 & Uncertain & Chironna et al. 2014 [42] \\
\hline 2011 & Ireland & In-flight catering & Milk tart and egg dish & $S$. Heidelberg & 25 & 5 & 0 & Uncertain & Rebolledo et al. 2014 [40] \\
\hline 2011 & $\begin{array}{l}\text { Germany, The } \\
\text { Netherlands }\end{array}$ & $\begin{array}{l}\text { Clinic and Asian } \\
\text { restaurants in } \\
\text { Germany, hospital in } \\
\text { The Netherlands }\end{array}$ & Mung bean sprouts & $S$. Newport & 126 & 38 & 0 & $\begin{array}{l}\text { Insufficient heat } \\
\text { treatment of } \\
\text { undercooked sprouts }\end{array}$ & Bayer et al. 2014 [41] \\
\hline 2014 & UK & $\begin{array}{l}\text { Hospital canteen, three } \\
\text { restaurants }\end{array}$ & $\begin{array}{l}\text { Eggs from a German } \\
\text { producer }\end{array}$ & S. Enteritidis & 287 & 78 & 1 & $\begin{array}{l}\text { Not reported, } \\
\text { probably } \\
\text { undercooked food }\end{array}$ & Inns et al. 2015 [43] \\
\hline
\end{tabular}

n.r., Not reported. 
community to reduce the risk of Salmonella in foods, recently Møller and colleagues [22] carried out a risk assessment of Salmonella in Danish meatballs produced in the catering sector. These authors determined that a temperature of $\sim 70^{\circ} \mathrm{C}$ at the core of the meatballs, using oven heating, significantly reduced the risk of Salmonella. The authors also found that the risk was low even with pan-frying provided that the meatballs were not exposed to conditions that allow the growth of the pathogen. As evidenced by the analysis of the scientific literature, the quality of raw materials can also be identified as a parameter of fundamental importance, especially when raw meats are consumed without cooking (e.g. carpaccio). Recently, Zweifel \& Stephan [47] shed light on the contribution of spices and herbs in Salmonella-related foodborne diseases. Usually, these ingredients are used either for the production of cured raw meat products not subjected to heating or for the seasoning of ready-to-eat products. The authors found frequencies of Salmonella-positive samples ranging from $0 \%$ to $8 \cdot 4 \%$. Zweifel \& Stephan [47] suggested that the microbiological status of spices and herbs should be carefully monitored by food business operators since these ingredients might constitute a threat for the contamination of end products.

As far as risk factors are concerned, some common elements were represented by the occurrence of crosscontaminations between heat-treated foods and raw materials (eggs and raw meat) or the inadequate application of GMPs. Moreover, a combination of factors such as structural deficiencies of the producing plant (e.g. the non-functional staff toilet) and infected members of staff was an acknowledged cause of risk. Despite epidemiological and microbiological investigations, in some of the reported cases it was not possible to discover the risk factors that contributed to the spread of Salmonella infections.

Since structural deficiencies can usually only be resolved by the allocation of considerable funds, one way to improve the hygiene conditions of catering facilities is to optimize the application of GMPs and act decisively on staff training.

It is well-known that, in food production environments, Salmonella can be particularly insidious, since it can persist thanks to its ability to adhere to several food contact surfaces, forming biofilms. Srey and colleagues [48] reported that Salmonella can produce biofilms on plastic surfaces used in the food industry. Moreover, it has also been found that this pathogen could demonstrate a different degree of adhesiveness to Teflon, stainless steel, glass, and polyurethane. In order to obtain safer foods Lianou \& Sofos [49], pointed out that structured training programmes for staff are essential. It is common knowledge that the contamination of foods (as well as cross-contamination) can be reduced by washing hands, the use of gloves, the separation of raw materials from end products, the sanitation and disinfection of equipment and food contact surfaces. Moreover, as reported by Luning and colleagues [50], the observation of food handlers with direct intervention to change incorrect behaviour can be useful for developing a greater food safety awareness.

On this subject, Powell and colleagues [51] reported that training programmes are often ineffective and their knowledge evaluation does not reflect real improvements in practices; on the contrary, Gormley and colleagues [52] state that trained staff have a greater knowledge of food safety than non-trained personnel.

The WHO Fact Sheet No. 139 [53] established a set of hygiene rules for food preparation addressed to food businesses. Among these, the WHO document states that professional food handlers who suffer from fever, diarrhoea, vomiting or visibly infected skin lesions should report these symptoms to their employer immediately. The WHO also set the following so-called 'Five Keys to Safer Food' as the basis for educational training programmes: keep clean, separate raw and cooked, cook thoroughly, keep food at safe temperatures, use safe water and raw materials. Although these recommendations may appear somewhat simple or obvious, an incorrect application of one or more of them, can lead to the failure of the entire prevention system.

\section{CONCLUSIONS}

The efforts made over the years by the European Legislative Bodies, by the EFSA and the ECDC and by the National Food Safety Authorities of EU MSs, have led to a progressive and significant reduction in salmonellosis cases related to catering and, more in general, to the food industry. These achievements should not underestimate the risk that Salmonella can still represent, since, even in recent years, there have been cases of salmonellosis related to the catering sector, hence, epidemiological and microbiological studies remain pivotal in order to trace the sources of contamination. In addition, the application of preventive measures based on the 
adoption of GMPs and the proper training of the staff continue to play a key role in ensuring the safety of foods.

\section{DECLARATION OF INTEREST}

None

\section{REFERENCES}

1. Álvarez-Ordóñez A, et al. The acid tolerance response of Salmonella spp.: an adaptive strategy to survive in stressful environments prevailing in foods and the host. Food Research International 2012; 45: 482-492.

2. Sánchez-Vargas FM, Abu-El-Haija MA, Gómez-Duarte OG. Salmonella infections: An update on epidemiology, management, and prevention. Travel Medicine and Infectious Disease 2011; 9: 263-277.

3. Forsythe SJ. The Microbiology of Safe Food, 2nd edn. Wiley-Blackwell, 2010.

4. Andrews JR, Ryan ET. Diagnostics for invasive Salmonella infections: current challenges and future directions. Vaccine 2015; 19: C8-15.

5. EFSA and ECDC. (European Food Safety Authority and European Centre for Disease Prevention and Control). The European Union summary report on trends and sources of zoonoses, zoonotic agents and food-borne outbreaks in 2014. EFSA Journal 2015; 13: 4329, $191 \mathrm{pp}$.

6. Hugas M, Beloeil PA. Controlling Salmonella along the food chain in the European Union - progress over the last ten years. Eurosurveillance 2014; 19: 1-4.

7. Smith AG, West A. Catering, catering systems. In: Encyclopedia of Food Sciences and Nutrition, 2nd edn, 2003, pp. 975-982.

8. Osimani A, et al. An eight-year report on the implementation of HACCP in a university canteen: impact on the microbiological quality of meals. International Journal of Environmental Health Research 2011; 21: 120-132.

9. Regulation (EC) No. 178/2002. European Parliament and of the Council of 28 January 2002 laying down the general principles and requirements of food law, establishing the European Food Safety Authority and laying down procedures in matters of food safety. Official Journal of the European Communities (http://eurlex.europa.eu/legal-content/EN/TXT/PDF/?uri=CELEX: $32002 \mathrm{R} 0178 \&$ from $=\mathrm{EN}$ ).

10. Regulation (EC) No. 852/2004. European Parliament and the Council of 29 April 2004 on the hygiene of foodstuffs. Official Journal of the European Union (http://eur-lex.europa.eu/LexUriServ/LexUriServ.do?uri= OJ:L:2004:139:0001:0054:en:PDF).

11. Regulation (EC) No. 853/2004. European Parliament and of the Council of 29 April 2004 laying down specific hygiene rules for food of animal origin. Official Journal of the European Union (http://eur-lex.europa.eu/Lex UriServ/LexUriServ.do?uri=OJ:L:2004:139:0055:0205: en:PDF).
12. Regulation (EC) No. 854/2004. European Parliament and of the Council of 29 April 2004 laying down specific rules for the organisation of official controls on products of animal origin intended for human consumption. Official Journal of the European Union (http://eur-lex. europa.eu/LexUriServ/LexUriServ.do?uri=OJ:L:2004:226: 0083:0127:EN:PDF).

13. Regulation (EC) No. 882/2004. European Parliament and of the Council of 29 April 2004 on official controls performed to ensure the verification of compliance with feed and food law, animal health and animal welfare rules. Official Journal of the European Union (http://eurlex.europa.eu/LexUriServ/LexUriServ.do?uri=OJ:L:2004: 165:0001:0141:EN:PDF).

14. Commission Regulation (EC) No. 2073/2005. Of 15 November 2005 on microbiological criteria for foodstuffs. Official Journal of the European Union (https:// www.fsai.ie/uploadedFiles/Reg2073_2005(1).pdf).

15. Commission Regulation (EC) No. 1441/2007. Of 5 December 2007 amending Regulation (EC) No 2073/ 2005 on microbiological criteria for foodstuffs. Official Journal of the European Union (http://eur-lex.europa.eu/ LexUriServ/LexUriServ.do?uri=OJ:L:2007:322:0012:0029: EN:PDF).

16. Directive 2003/99/EC. European Parliament and of the Council of 17 November 2003 on the monitoring of zoonoses and zoonotic agents, amending Council Decision 90/424/EEC and repealing Council Directive 92/117/ EEC. Official Journal of the European Union (http://eurlex.europa.eu/LexUriServ/LexUriServ.do?uri=OJ:L:2003: 325:0031:0040:EN:PDF).

17. Council Decision. Of 19 December 2006 amending Decision 90/424/EEC on expenditure in the veterinary field. Official Journal of the European Union (http://eurlex.europa.eu/LexUriServ/LexUriServ.do?uri=OJ:L:2006: 397:0022:0027:EN:PDF).

18. Council Directive 92/117/EEC. Of 17 December 1992 concerning measures for protection against specified zoonoses and specified zoonotic agents in animals and products of animal origin in order to prevent outbreaks of food-borne infections and intoxications (http://ec.eur opa.eu/food/fs/sfp/mr/mr07_en.pdf).

19. Decision No. 1082/2013/EU. European Parliament and of the Council of 22 October 2013 on serious crossborder threats to health and repealing Decision No 2119/98/EC. Official Journal of the European Union (http://ec.europa.eu/health/preparedness_response/docs/ decision_serious_crossborder_threats_22102013_en.pdf).

20. Decision No. 2119/98/EC. European Parliament and of the Council of 24 September 1998 setting up a network for the epidemiological surveillance and control of communicable diseases in the Community. Official Journal of the European Communities (http://eur-lex.europa.eu/ resource.html?uri=cellar:b97abla4-21f5-49de-9964-bc25 $617 \mathrm{~d} 3485.0008 .02 / D O C \_1 \&$ format=PDF).

21. Lund BM. Microbiological food safety for vulnerable people. International Journal of Environmental Research and Public Health 2012; 12: 10117-10132.

22. Møller COA, et al. Risk assessment of Salmonella in Danish meatballs produced in the catering sector. 
International Journal of Food Microbiology 2015; 196: 109-125.

23. Cowden J, et al. A national outbreak of infection with Salmonella enteritidis phage types $5 \mathrm{c}$ and $6 \mathrm{a}$ associated with Chinese food businesses in Scotland, summer 2000. Epidemiology and Infection 2003; 130: 387-393.

24. Badrinath $\mathbf{P}$, et al. An outbreak of Salmonella enteritidis phage type 34a infection associated with a Chinese restaurant in Suffolk, United Kingdom. BMC Public Health 2004; 1: 4- 40.

25. Ethelberg S, et al. Prolonged restaurant-associated outbreak of multidrug-resistant Salmonella Typhimurium among patients from several European countries. Clinical Microbiology and Infection 2004; 10: 904-910.

26. Little CL, et al. Public health investigations of Salmonella Enteritidis in catering raw shell eggs, 2002-2004. Letters in Applied Microbiology 2007; 44: 595-601.

27. Hadjichristodoulou C, et al. Management of environmental health issues for the 2004 Athens Olympic Games: is enhanced integrated environmental health surveillance needed in every day routine operation? BMC Public Health 2006; 6: 306.

28. Irvine WN, et al. Investigation of an outbreak of Salmonella enterica serovar Newport infection. Epidemiology and Infection 2009; 137: 1449-1456.

29. Heissenhuber A, et al. Accumulated occurrence of illnesses with Salmonella enteritidis in hospitals and nursing homes in the district Oberallgaeu, Bavaria, in July 2004. Gesundheitswesen 2005; 67: 845-852.

30. Gikas A, et al. A nosocomial, foodborne outbreak of Salmonella Enterica serovar Enteritidis in a university hospital in Greece: the importance of establishing HACCP systems in hospital catering. Journal of Hospital Infection 2007; 66: 194-196.

31. Giraudon I, et al. Large outbreak of Salmonella phage type 1 infection with high infection rate and severe illness associated with fast food premises. Public Health 2009; 123: 444-447.

32. Ethelberg S. Salmonellosis outbreak linked to carpaccio made from imported raw beef, Denmark, June-August 2005. Eurosurveillance 2005; 10: pii $=2796$.

33. Ethelberg S. et al. Outbreak of multi-resistant Salmonella Typhimurium DT104 linked to carpaccio, Denmark, 2005. Epidemiology and Infection 2005; 135: 900-907.

34. Lienemann T, et al. Iceberg lettuce as suggested source of a nationwide outbreak caused by two Salmonella serotypes, Newport and Reading, in Finland in 2008. Journal of Food Protection 2011; 74: 1035-1040.

35. Janmohamed K, et al. National outbreak of Salmonella Enteritidis phage type $14 \mathrm{~b}$ in England, September to December 2009: case-control study. Eurosurveillance 2011; 16: pii: 19840 .

36. Zenner D, et al. Till receipts - a new approach for investigating outbreaks? Evaluation during a large Salmonella Enteritidis phage type $14 \mathrm{~b}$ outbreak in a north west London takeaway restaurant, September 2009. Eurosurveillance 2014; 19: pii $=20848$.
37. Liu YL, et al. A 2010 Austrian Salmonella enteritidis PT4 outbreak associated with a laying hen holding previously involved in an $S$. enteritidis PT4 cluster: pitfalls of regulatory responses in risk management. Journal of Infection and Public Health 2012; 5: 332-339.

38. Poetter C, et al. Containment of a cheesecake-associated outbreak of salmonellosis in 3 different hospitals, detected by continuous microbiologic surveillance. American Journal of Infection Control 2014; 42: 816-817.

39. Gobin M, et al. National outbreak of Salmonella Java phage type $3 \mathrm{~b}$ variant 9 infection using parallel casecontrol and case-case study designs, United Kingdom, July to October 2010. Eurosurveillance 2011; 16: 20023.

40. Rebolledo J, et al. International outbreak investigation of Salmonella Heidelberg associated with in-flight catering. Epidemiology and Infection 2014; 142: 833-842.

41. Bayer C, et al. An outbreak of Salmonella Newport associated with mung bean sprouts in Germany and the Netherlands, October to November 2011. Eurosurveillance $2014 ;$ 19: pii $=20665$.

42. Chironna M, et al. Outbreak of Salmonella Infantis gastroenteritis among people who had eaten at a hash house in southern Italy. Public Health 2014; 128: 438-443.

43. Inns T, et al. A multi-country Salmonella Enteritidis phage type $14 \mathrm{~b}$ outbreak associated with eggs from a German producer: near 'real-time' application of whole genome sequencing and food chain investigations, United Kingdom, May to September 2014. Eurosurveillance 2015; 20: pii $=21098$.

44. European Centre for Disease Prevention and Control (ECDC). Annual epidemiological report 2014 -foodand waterborne diseases and zoonoses. Stockholm: ECDC, 2014.

45. Food Safety Authority of Ireland (FSAI). Salmonella spp. and Eggs, Food Safety Advice for Caterers. Microbial Fact Sheet Series, Issue No. 1, May 2010.

46. European Centre for Disease Prevention and Control, European Food Safety Authority. Multi-country outbreak of Salmonella Enteritidis infections associated with consumption of eggs from Germany - 25 August 2014. Stockholm and Parma: ECDC/EFSA, 2014 (http://www.efsa.europa.eu/sites/default/files/scientific_ output/files/main_documents/646e.pdf).

47. Zweifel C, Stephan R. Spices and herbs as source of Salmonella-related foodborne diseases. Food Research International 2012; 45: 765-769.

48. Srey S, Jahid IK, Ha S-D. Biofilm formation in food industries: A food safety concern. Food Control 2013; 31: 572-585

49. Lianou A, Sofos JN. A review of the incidence and transmission of Listeria monocytogenes in ready-to-eat products in retail and food service environments. Journal of Food Protection 2007; 70: 2172-2198.

50. Luning PA, et al. Systematic assessment of core assurance activities in a company specific food safety management system. Trends in Food Science \& Technology 2009; 20: 300-312. 
51. Powell DA, Jacob CJ, Chapman BJ. Enhancing food safety culture to reduce rates of foodborne illness. Food Control 2011; 22: 817-822.

52. Gormley FJ, Rawal N, Little CL. Choose your menu wisely: cuisine-associated food-poisoning risks in restaurants in England and Wales. Epidemiology and Infection 2012; 140: 997-1007.

53. World Health Organization. Salmonella (nontyphoidal). Fact Sheet, No. 139, 2013 (http://www. who.int/mediacentre/factsheets/fs139/en/). 